Research article

urn:1sid:zoobank.org:pub:DCD171EC-6709-4495-85B3-6430E85C529E

\title{
New records of Dasyhelea Kieffer, 1911 from Sweden, with descriptions of two new species (Diptera: Ceratopogonidae)
}

\author{
Jonas STRANDBERG ${ }^{1,2,3, *}$ \& Kjell Arne JOHANSON ${ }^{1,4}$ \\ ${ }^{1}$ Swedish Museum of Natural History, Department of Zoology, Box 50007, \\ 10405 Stockholm, Sweden \\ ${ }^{2}$ Stockholm University, Department of Zoology, 10691 Stockholm, Sweden \\ * Corresponding author: jonas.strandberg@nrm.se \\ ${ }^{3}$ urn:1sid:zoobank.org:author:EDE10C9E-737E-4F88-9FFF-219BDC80F8BA \\ ${ }^{4}$ urn:Isid:zoobank.org:author:F2A38CF6-59EB-4F88-BFEB-761DBEA7B01A
}

\begin{abstract}
Based on intensive collecting from various sites in Sweden, the genus Dasyhelea Kieffer, 1911 was reviewed and the number of species now known from the country increased from five to twenty. Among the new species recorded there are two species described as new to science, D. dominiakae sp. nov. and D. gothlandica sp. nov., both in the subgenus Dicryptoscena Enderlein, 1936. The following subgenera are now documented from Sweden: Dasyhelea, Dicryptoscena, Pseudoculicoides Malloch, 1915, Prokempia Kieffer, 1913 and Sebessia Remm, 1979, the two latter subgenera being reported for the first time.
\end{abstract}

Keywords. Biting midges, taxonomy, systematics, new species, Malaise trap.

Strandberg J. \& Johanson K.A. 2015. New records of Dasyhelea Kieffer, 1911 from Sweden, with descriptions of two new species (Diptera: Ceratopogonidae). European Journal of Taxonomy 131: 1-22. http://dx.doi.org/10.5852/ ejt.2015.131

\section{Introduction}

The genus Dasyhelea Kieffer, 1911 is classified in the subfamily Dasyheleinae Lenz, 1934 and is cosmopolitan in distribution. More than 600 Dasyhelea species are known, representing one-tenth of all described Ceratopogonidae species in the World (Borkent 2015). The highest diversity is described from large countries in the northern hemisphere, i.e., China, USA and Russia (Borkent 2015). The immature stages of Dasyhelea inhabit a wide range of moist and terrestrial habitats, like peat bogs (Domniak \& Szadziewski 2006), rockpools (Wirth 1978), plants of Nepenthes Linnaeus (Wirth \& Beaver 1979), tree sap (Domniak 2005) and in mushrooms (Graves \& Graves 1985). The short-lived adults (ZilahiSebess 1931) are often found in or around the vegetation near the breeding sites (Waugh \& Wirth 1976). The structure of the mouthparts in both sexes is similar, i.e., reduction of both mandibles and maxillae (Glukhova 1981), and both males and females feed on nectar and honeydew and according to Wirth (1956) they can act as pollinators of plants such as rubber trees (Hevea brasiliensis (Willd. ex Adr. Juss.)).

The most recently described ceratopogonid species from Sweden, which are still valid, are Forcipomyia squamigera Kieffer, 1916 and Bezzia pilipennis Lundström, 1916. Reports thereafter added more species 
records for the country, resulting in a record list of approximately one hundred species of Ceratopogonidae for Sweden (Rehnberg \& Brodin 2010; Nielsen et al. 2010; Szadziewski et al. 2012). This may be compared to 184 species in Estonia, 211 in Poland and 256 in Germany (Szadziewski et al. 2012), which indicates that Sweden might have been undersampled historically compared to some other countries. Efforts were therefore made in order to more carefully examine the Swedish diversity using recently trapped material from various sites. The Swedish Dasyhelea include five species previously recorded from Sweden: D. pallidiventris (Goetghebuer, 1931), D. corinneae Gosseries, 1991, D. turficola Kieffer, 1925, D. modesta (Winnertz, 1852) and D. notata Goetghebuer, 1920 (Dominiak \& Szadziewski 2010). With this report the number of Dasyhelea species in Sweden increases to 20, a low number compared to the more than 60 species recorded from the rest of Europe (Szadziewski et al. 2012).

\section{Material \& Methods}

The specimens in this study were collected from Djäknabygds Bokbacke during the summer of 2005, from Limhmans kalkbrott (limestone quarry) during the summer of 2009, and various other localities in Sweden during the spring and summer of 2011. Specimens were collected in Malaise traps and in sweep nets. At the lab they were stored in $80 \%$ ethanol in deep freezers. After sorting and preliminary identification, the whole body was cleared using Proteinase K as part of DNA extraction and sequenced for mitochondrial cytochrome I (COI) according to the methods described in Strandberg \& Johanson (2010). The COI sequences were used to associate males and females using MEGA 5.2.2 (Tamura et al. 2011), applying the settings in Stur \& Borkent (2014). The head, wings and abdomen/genitals from the thorax and one leg from each leg pair were mounted under separate cover slips on microscope slides using Euparal as permanent mounts. Specimens from Limhamns kalkbrott and Bunkeflostrand are stored at the Museum of Zoology, Lund University, Sweden (MZLU) while the rest are deposited at the Department of Zoology, Swedish Museum of Natural History (NHRS).

In the descriptions, specimens were measured for each character and ratios and measurements of the antennae (AR), palpi $\left(\mathrm{PR}_{(\mathrm{IIII}}\right)$, wings and costal vein $(\mathrm{CR})$ were obtained following the methods described by Dominiak (2012). Measurements are given for the holotype as well as the range of variation in each character for the paratypes ( $\mathrm{n}=$ number of specimens examined).

\section{Results}

Class Insecta Linnaeus, 1758

Order Diptera Linnaeus, 1758

Family Ceratopogonidae Newman, 1834

Subfamily Dasyheleinae Lenz, 1934

Genus Dasyhelea Kieffer, 1911

Dasyhelea Kieffer, 1911: 5. Type species: Dasyhelea halophila Kieffer, 1911: 5 (by monotypy).

Subgenus Dasyhelea

Dasyhelea (Dasyhelea) bensoni Edwards, 1933

Dasyhelea bensoni Edwards, 1933: 91.

Dasyhelea vernalis Remm, 1979: 56.

\section{New record}

SWEDEN: 2 ઈð̊, Gällivare, Muddus National Park, Lake Muddus, $67.030916^{\circ} \mathrm{N}, 20.254950^{\circ} \mathrm{E}$, 418 masl, loc. 036-01, Malaise trap, 7-20 Jun. 2011, leg. H. Gustafsson (NHRS). 


\section{Distribution}

Great Britain, Norway, Estonia, Romania, Russia (Amur Oblast, Yakutia) (Dominiak \& Szadziewski 2010).

\section{Biology}

Specimens were collected on mire close to a lake during mid June. Previously $D$. bensoni has been collected from the end of May to mid July (Edwards 1933; Remm 1979).

Dasyhelea (Dasyhelea) bilineata Goetghebuer, 1920

Dasyhelea bilineata Goetghebuer, 1920: 45.

Dasyhelea insignipalpis Kieffer, 1925a: 62 (as D. versicolor var. insignipalpis).

Tetraphora saxicola Edwards, 1929: 426.

Dasyhelea geleiana Zilahi-Sebess, 1931: 321.

Dasyhelea montana Zilahi-Sebess, 1940: 48 (as D. dufouri var montana).

Dasyhelea lithotelmatica Strenzke in Thienemann, 1950: 178.

Dasyhelea tecticola Remmert, 1953: 334.

Culicoides dieuzeidei Vaillant, 1957: 265.

Dasyhelea karelica Glukhova \& Brodskaya, 1997: 443.

\section{New record}

SWEDEN: 1 đ̃, 1 q, Malmö, Bunkeflostrand, Malaise trap, 16 Jul.-1 Aug. 2009, leg. B.W. Svensson (MZLU).

\section{Distribution}

Norway, Finland, Russia, Estonia, Great Britain, Ireland, Belgium, Germany, Poland, Czech Republic, Slovakia, France, Switzerland, Austria, Italy, Croatia, Hungary, Romania, Ukraine (Crimea), Bulgaria, Spain, Gibraltar, Algeria, Turkey (Dominiak \& Szadziewski 2010).

\section{Biology}

The specimens were collected in an area with shore meadows on the west coast in the south of Sweden. The larva inhabits shallow water bodies; both natural and artificial and preimaginal stages are very tolerant of desiccation and temperature fluctuations (Zilahi-Sebess 1931; Valkanov 1941; Disney 1975).

\section{Remarks}

The male keys out as D. bilineata in Dominiak (2012). The associated female has the subgenital plate with broad lateral processes and a more hearth-shaped notum in contrast to the isosceles triangularshaped notum of D. bilineata shown in Dominiak (2012).

\section{Dasyhelea (Dasyhelea) caesia Remm, 1993}

Dasyhelea caesia Remm, 1993: 193.

Dasyhelea lugensis Brodskaya, 1995: 9.

\section{New record}

SWEDEN: 1 đ̊ , Haninge, Tyresta National Park, Löpanträsk, 59.182483 N, $18.303100^{\circ}$ E, 40 masl, loc. 025-07, Malaise trap, 19 Jul.-2 Aug. 2011, leg. J. Strandberg (NHRS). 


\section{Distribution}

Russia (Leningrad Oblast, Yakutia), Poland (Dominiak \& Szadziewski 2010).

\section{Biology}

The specimen was collected in a marsh situated between two lakes with water flowing through. Last instar larvae and pupae of Dasyhelea caesia have previously been collected from a small body of water and the littoral zone of lakes in Russia during July (Brodskaya 1995; Przhiboro 2005).

\section{Dasyhelea (Dasyhelea) malleola Remm, 1962}

Dasyhelea malleolus Remm, 1962: 119.

\section{New records}

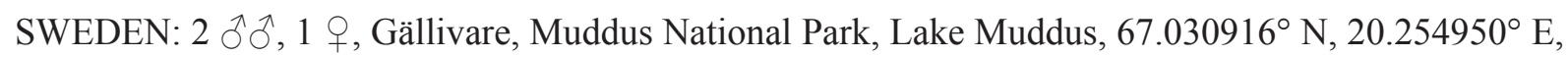
418 masl, loc. 036-01, Malaise trap, 7-20 Jun. 2011, leg. H. Gustafsson (NHRS); 1 đ, 3 $q$, Gällivare, Muddus National Park, Lake Muddus, $67.030916^{\circ} \mathrm{N}, 20.254950^{\circ} \mathrm{E}, 418$ masl, loc. 036-02, Malaise trap, 20 Jun.-3 Jul. 2011, leg. H. Gustafsson (NHRS); 2 ๙ิ ô, Gällivare, Muddus National Park, $67.049916^{\circ}$ N, 20.256533 ${ }^{\circ}$ E, 443 masl, loc. 037-01, Malaise trap, 7-20 Jun. 2011, leg. H. Gustafsson (NHRS); 1 , Gällivare, Muddus National Park, 67.049916 N, 20.256533ํㅡ, 443 masl, loc. 037-02, Malaise trap, 20 Jun.-3 Jul. 2011, leg. H. Gustafsson (NHRS).

\section{Distribution}

Estonia, Norway, Germany, Poland, Czech Republic, Ukraine (Crimea), Spain, Andorra, Algeria (Dominiak \& Szadziewski 2010; Stur \& Borkent 2014).

\section{Biology}

Specimens were collected on mire next to a lake from the beginning of June to the beginning of July.

\section{Dasyhelea (Dasyhelea) flavifrons (Guérin, 1833)}

Ceratopogon flavifrons Guérin, 1833: 165.

Ceratopogon obscurus Winnertz, 1852: 45.

Ceratopogon versicolor Winnertz, 1852: 45.

Ceratopogon dufouri Laboulbène, 1869: 158.

Ceratopogon hippocastani Mik, 1888: 185.

Ceratopogon rufithorax Strobl, 1920: 261 (as C. versicolor var. rufithorax).

Dasyhelea brevitibialis Goetghebuer, 1919: 72.

Dasyhelea goetghebueri Kieffer, 1919: 53.

Dasyhelea sensualis Kieffer, 1919: 55.

Dasyhelea lignicola Kieffer, 1919: 57.

Dasyhelea paludicola Kieffer, 1925b: 152.

Dasyhelea opressa Thomsen, 1935: 285.

Dasyhelea septuosa Borkent in Borkent \& Wirth, 1997: 58 (new name for D. obscura (Winnertz, 1852)).

\section{New record}

SWEDEN: 1 đె, Nybro, Alsterbro, Alsterån, 56.936536 N, $15.920167^{\circ}$ E, Trap ID 1008, collecting event 1743, Malaise trap, 16-22 Jul. 2006, leg. Swedish Malaise Trap Project (NHRS). 


\section{Distribution}

Estonia, Great Britain, Belgium, Germany, Poland, Czech Republic, France, Austria, Switzerland, Spain, Croatia (Istria), Greece (Crete), Bulgaria, Ukraine (Crimea), Russia (Karachay-Cherkessia), USA (Dominiak \& Szadziewski 2010).

\section{Biology}

Larvae of D. flavifrons can be found in tree sap or tree holes. Flight period May-October (Dominiak 2012).

\section{Remarks}

The previous listing of this species as present in Sweden is doubtful as it has only been reported in Rehnberg \& Brodin (2010), based on D. versicolor (Winnertz, 1852) as listed in Szadziewski et al. (1997). We were unable to verify previous records.

\section{Dasyhelea (Dasyhelea) pallidiventris (Goetghebuer, 1931)}

Tetraphora pallidiventris Goetghebuer, 1931: 211.

Dasyhelea olivacea Remm, 1962: 117.

\section{Distribution}

Sweden, Finland, Estonia, Lithuania, Germany, Poland, Czech Republic, Ukraine (Crimea), Georgia, Azerbaijan, North Korea (Dominiak \& Szadziewski 2010).

\section{Biology}

Dasyhelea pallidiventris is considered a haloxene, and the larvae inhabit inland saline habitats and the littoral zone of lakes (Szadziewski 1983). Previously recorded from Norrtälje in east-central Sweden (Dominiak \& Szadziewski 2010).

Subgenus Prokempia Kieffer, 1913

Prokempia Kieffer, 1913a: 163, 179. Type species: Dasyhelea ornaticornis Kieffer, 1913a: 180 (designated by Wirth 1973: 358).

Dasyhelea (Prokempia) biunguis Kieffer, 1925

Dasyhelea biunguis Kieffer 1925c: 409.

\section{New record}

SWEDEN: 1 đ̊, 1 \&, Älmhult, Stenbrohult, Djäknabygds bokbacke, $56.609133^{\circ} \mathrm{N}, 14.193050^{\circ} \mathrm{E}$, Trap ID 24, collecting event 1673, Malaise trap, 31 May-20 Jul. 2005, leg. Swedish Malaise Trap Project (NHRS).

\section{Distribution}

Great Britain, Norway, Estonia, Russia (Kaliningrad Oblast) (Dominiak \& Szadziewski 2010).

\section{Biology}

Specimens collected on a heath with old beeches. 
Dasyhelea (Prokempia) dampfi Kieffer, 1925

Dasyhelea dampfi Kieffer, 1925b: 150.

Dasyhelea turfacea Kieffer, 1925b: 151.

Dasyhelea estonica Kieffer, 1925c: 409.

\section{New record}

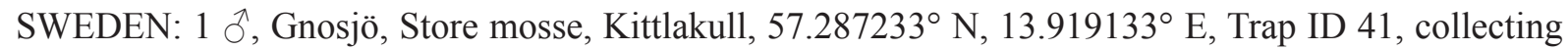
event 1159, Malaise trap, 3-6 Aug. 2004, leg. Swedish Malaise Trap Project (NHRS).

\section{Distribution}

Estonia, Lithuania, Poland, Czech Republic (Dominiak \& Szadziewski 2010).

\section{Biology}

This specimen was collected at a peat bog in the beginning of August.

Subgenus Pseudoculicoides Malloch, 1915

Pseudoculicoides Malloch, 1915: 309. Type species: Ceratopogon mutabilis Coquilett, 1901: 602 (by orginal designation).

\section{Dasyhelea (Pseudoculicoides) arenivaga Macfie, 1943}

Dasyhelea inconspicuosa var. arenivaga Macfie, 1943: 151.

\section{New records}

SWEDEN: 1 đ, 1 우, Gotland, $57.847400^{\circ}$ N, $18.811216^{\circ}$ E, 3 Jul. 2011, 6 masl, net, leg. J. Strandberg

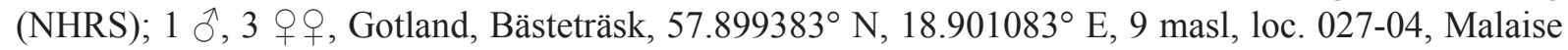
trap, 28 May-12 Jun. 2011, leg. B. Eklund (NHRS).

\section{Distribution}

Poland, Czech Republic, Switzerland, Romania, Ukraine (Crimea), Bulgaria, Spain, Algeria, Egypt, Israel, United Arab Emirates (Dominiak \& Szadziewski 2010; Szadziewski et al. 2011).

\section{Biology}

These specimens were collected in a marsh and in a seasonally flooded area next to a lake. D. arenivaga is known to visit umbelliferous and tamarisk flowers (Dominiak \& Szadziewski 2010).

Dasyhelea (Pseudoculicoides) calycata Remm, 1972

Dasyhelea calycata Remm, 1972: 74.

\section{New record}

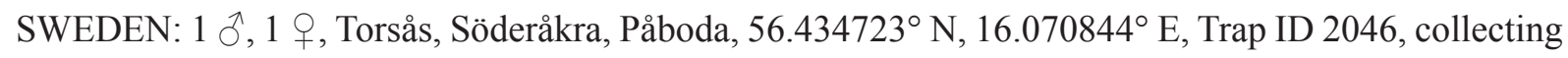
event 2058, Malaise trap, 1 Sep.-3 Oct. 2008, leg. Swedish Malaise Trap Project (NHRS).

\section{Distribution}

Great Britain, Lithuania, Poland, Slovakia, Bosnia and Herzegovina, Ukraine (Crimea), Romania, Bulgaria, Spain, Hungary, Russia (North Ossetia, Tuva, Buryatia), Mongolia (Dominiak \& Szadziewski 2010). 


\section{Biology}

The specimens were collected in a small village garden. Larvae can be found in both fresh and salt-water habitats and are common on inland saline meadows in Poland (Dominiak 2012).

\section{Remarks}

The association of the sexes made by Remm (1972) has previously been considered incorrect. The associated female probably belongs to D. unguistyla Remm, 1972 (Dominiak \& Szadziewski 2010). The female associated in this study by COI sequences differs from the original description in lacking long cerci and in having a subgenital plate with a lumen. According to Dominiak \& Szadziewski (2010) the type material is unavailable.

\section{Dasyhelea (Pseudoculicoides) corinneae Gosseries, 1991}

Ceratopogon scutellatus Meigen, 1830: 262.

Dasyhelea corinneae Gosseries, 1991: 42 (new name for D. scutellatus Meigen, 1830).

Dasyhelea chonetus Yu \& Zou in Yu et al., 2006: 279.

\section{Distribution}

Great Britain, Sweden, Poland, Hungary, Ukraine, Russia (North Ossestia, Ussuri Land), China, North Korea, Canada, USA (Dominiak \& Szadziewski 2010).

\section{Biology}

The only specimen recorded from Sweden was collected at Antjärn in August (Dominiak \& Szadziewski 2010).

Dasyhelea (Pseudoculicoides) europaea Remm, 1962

Dasyhelea europaea Remm, 1962: 122.

\section{New records}

SWEDEN: 1 ô, Gällivare, Muddus National Park, 67.049916 N, 20.256533 E, 443 masl, loc. $037-$ 01, Malaise trap, 7-20 Jun. 2011, leg. H. Gustafsson (NHRS); $1 \mathrm{\delta}^{\wedge}$, Gotland, Lärbro, 57.847400 ${ }^{\circ} \mathrm{N}$, $18.811216^{\circ}$ E, 6 masl, net, 3 Jul. 2011, leg. J. Strandberg (NHRS).

\section{Distribution}

Norway, Estonia, France, Czech Republic (Dominiak \& Szadziewski 2010).

\section{Biology}

Specimens collected on mire in the north of Sweden and from the vegetation in a marsh in the southeast of Sweden. It is reported as a spring-summer species, most common between May and June (Remm 1962).

\section{Dasyhelea (Pseudoculicoides) turficola Kieffer, 1925}

Dasyhelea turficola Kieffer, 1925a: 15.

Dasyhelea grenieri Clastrier, 1966: 703.

Dasyhelea malibui Yu, 2008: 165. 


\section{Distribution}

Great Britain, Ireland, Sweden, Estonia, Lithuania, Russia (Kaliningrad Oblast, Ussuri Land), Poland, Czech Republic, Belgium, France, Spain (Iberian Peninsula, Canaries: Tenerife), Georgia, Morocco, Algeria, Israel (Dominiak \& Szadziewski 2010).

\section{Biology}

Dasyhelea turficola larvae are known to inhabit peat bogs and moist soil close to fresh and salt-water bodies. Adults of the species visit umbelliferous flowers (Dominiak 2012). Previously, D. turficola have been collected in Johannisfors (Dominiak \& Szadziewski 2010).

\section{Subgenus Dicryptoscena Enderlein, 1936}

Dicryptoscena Enderlein, 1936: 51. Type species Dasyhelea inclusa Kieffer, 1918: 188 (by original designation).

Dasyhelea (Dicryptoscena) modesta (Winnertz, 1852)

Ceratopogon modestus Winnertz, 1852: 43.

Ceratopogon aestivus Winnertz, 1852: 42.

Dasyhelea longipalpis Kieffer, 1913b: 37.

Dasyhelea inclusa Kieffer, 1918: 188.

Dasyhelea strobli Kieffer, 1919: 63.

Dasyhelea pratensis Goetghebuer, 1920: 44.

Dasyhelea bihamata Kieffer, 1923: 667.

Dasyhelea moascari Macfie, 1943: 153.

Dasyhelea densipilosa Tokunaga, 1963: 41.

\section{Distribution}

Norway, Sweden, Russia (Karelia, Leningrad Oblast, North Ossetia), Estonia, Lithuania, Great Britain, Poland, Germany, the Netherlands, Belgium, Czech Republic, France, Switzerland, Austria, Hungary, Romania, Ukraine (Crimea), Bulgaria, Andorra, Spain, Georgia, Azerbaijan, Afghanistan, Iran, China, Japan, Algeria, Egypt, Yemen (Dominiak \& Szadziewski 2010).

\section{Biology}

Preimaginal stages inhabit a wide range of aquatic and semiaquatic habitats and can be found in ponds, mud, swamps, peat bogs, the littoral zone of lakes and saline habitats (Thienemann 1915, 1950; Mayer 1934; Szadziewski 1986; Przhiboro 1999; Chandler et al. 2008).

\section{Dasyhelea (Dicryptoscena) notata Goetghebuer, 1920}

Dasyhelea notata Goetghebuer, 1920: 47.

Dasyhelea semistriata Goetghebuer, 1921: 176.

Dasyhelea sziladyi Zilahi-Sebess, 1936: 42.

\section{Distribution}

Sweden, Finland, Estonia, Lithuania, Poland, Belgium, France, Switzerland, Czech Republic, Hungary, Romania, Spain, Georgia, Russia (Ussuri Land), North Korea, Algeria (Dominiak \& Szadziewski 2010). 


\section{Biology}

Adults of this species are known to visit umbelliferous flowers (Dominiak 2012).

Dasyhelea (Diryptoscena) stellata Remm, 1968

Dasyhelea stellata Remm in Remm \& Zhogolev, 1968: 831.

\section{New record}

SWEDEN: 2 ふึ̊ึ, Malmö, Limhamns kalkbrott, 2-“planen”, Malaise trap, 11-25 Jun. 2009, leg. B.W. Svensson \& Co. (MZLU).

\section{Distribution}

Great Britain, Poland, France, Czech Republic, Ukraine (Crimea), Russia (North Ossetia) (Dominiak \& Szadziewski 2010).

\section{Biology}

These specimens were collected close to a pond in an old limestone quarry in the south of Sweden.

Dasyhelea (Dicryotoscena) thienemanni Spâtaru \& Damian-Georgescu, 1970

Dasyhelea thienemanni Spâtaru \& Damian-Georgescu, 1970: 425.

\section{New records}

SWEDEN: 2 えð, Norrtälje, Svartsjön, $60.123098^{\circ} \mathrm{N}, 18.615078^{\circ}$ E, 2 masl, loc. 020-01, Malaise trap,

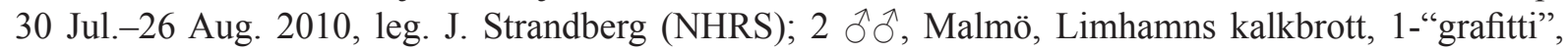
Malaise trap, 26 Jun.-8 Jul. 2009, leg. B.W. Svensson \& Co. (MZLU).

\section{Distribution}

Estonia, Lithuania, Poland, Slovakia, Hungary, Romania, Bulgaria, Georgia, Azerbaijan (Dominiak \& Szadziewski 2010).

\section{Biology}

The specimens were collected from a small peat-bog in the middle-east of Sweden and from an old limestone quarry in the south of Sweden. Preimaginal stages have previously been found in and around a spring (Spâtaru \& Damian-Georgescu 1970).

Dasyhelea (Dicryptoscena) dominiakae sp. nov. urn:1sid:zoobank.org:act:956852B2-A7AD-46A6-A238-0F8B55540915

Figs $1-11$

\section{Diagnosis}

The male resembles those of $D$. notata in the morphology of the genitalia, particularly by the presence of a pair of horn-like projections on the posterior margin of sternite 9. It is distinguished from D. notata in having an additional triangular projection on each lateral side of the posterior margin of sternite 9 .

\section{Etymology}

This species is named after Dr. Patrycja Dominiak for her contributions to our knowledge of European Ceratopogonidae, notably the Dasyhelea. 

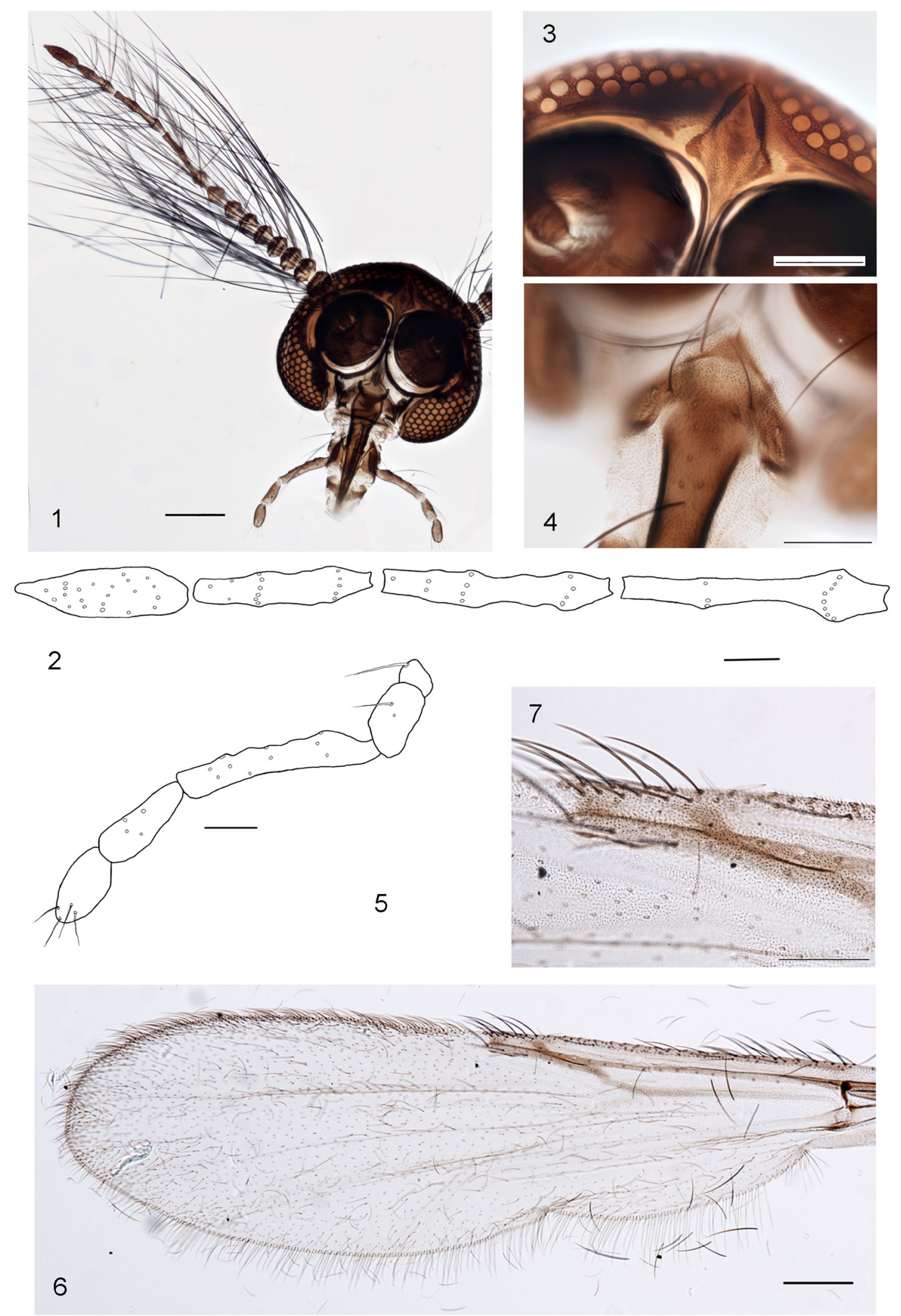

Figs 1-7. Dasyhelea dominiakae sp. nov., holotype, $\widehat{\jmath}$.1. Head. 2. Distal flagellomeres. 3. Frontal sclerite. 4. Clypeus. 5. Palp. 6. Wing. 7. First and second radial cell of wing. Scale bars: 1, $6=100 \mu \mathrm{m} ; 3-4$, $7=50 \mu \mathrm{m} ; 2,5=25 \mu \mathrm{m}$. 


\section{Type material}

\section{Holotype}

SWEDEN: §ૈ, Skåne, Malmö, Limhamns kalkbrott, 2-“planen”, Malaise trap, 11-25 Jun. 2009, leg. B.W. Svensson \& Co. (MZLU) (DNA voucher: 4DT).

\section{Paratypes}

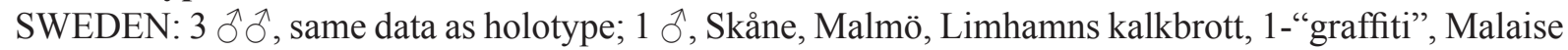
trap, 28 May-10 Jun. 2009, leg. B.W. Svensson \& Co. (MZLU).

\section{Description}

\section{Male}

HeAD (Figs 1-5). Antennal flagellum length $717 \mu \mathrm{m}(697-747 \mu \mathrm{m}, \mathrm{n}=4)$; AR $1.15(1.0-1.28, \mathrm{n}=4)$ (Fig. 2). Frontal sclerite rhomboid (Fig. 3). Clypeus entire, with $12(11-12, n=4)$ long setae (Fig. 4). Palp segment 3 slender, $95 \mu \mathrm{m}(95 \mu \mathrm{m}, \mathrm{n}=4)$; $\mathrm{PR}_{\text {(III) }} 5.4(4.75-6.3, \mathrm{n}=4)$; first half with hyaline sensillae on inner surface (Fig. 5).

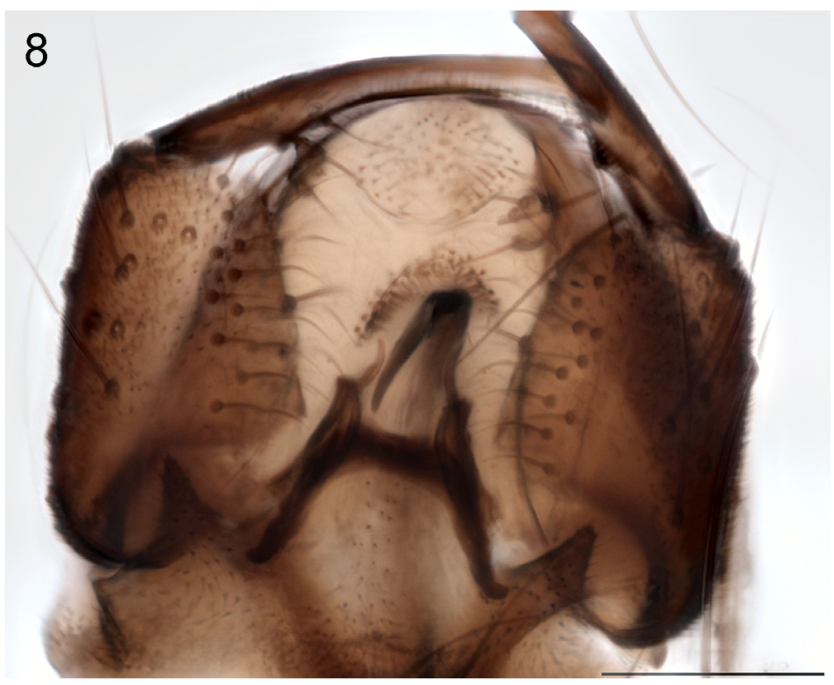

10

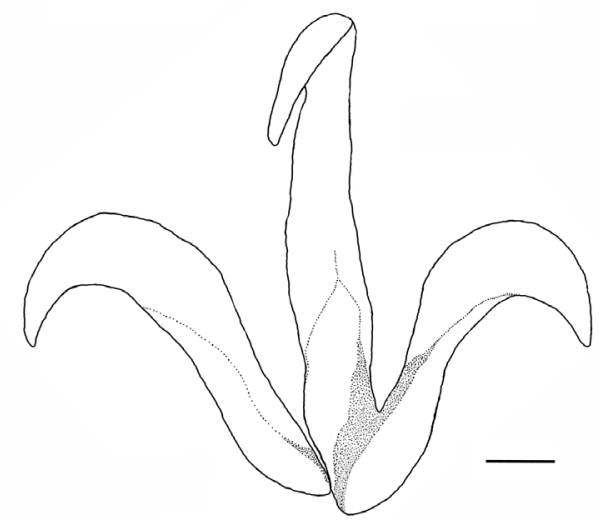

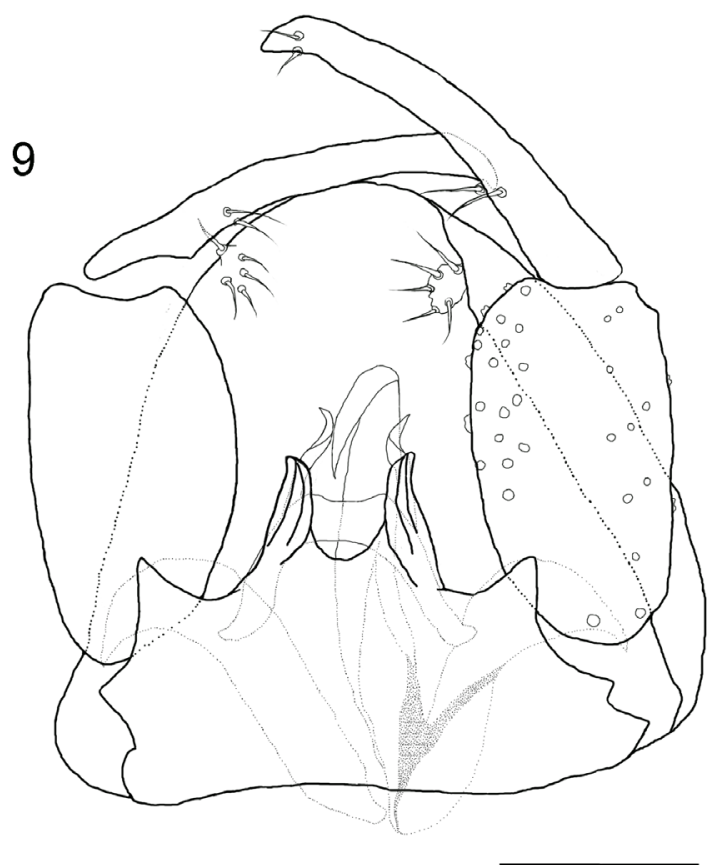

11

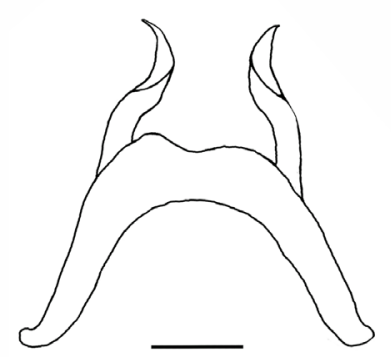

Figs 8-11. Dasyhelea dominiakae sp. nov., holotype, $\widehat{\jmath}$. 8-9. Ventral aspect of genitalia. 10. Parameres. 11. Aedeagus. Scale bars: $8-9=50 \mu \mathrm{m} ; 10-11=16 \mu \mathrm{m}$. 
Thorax (Figs 6-7). Scutellum pale, with 12 bristles (8-11, $\mathrm{n}=4)$. Wing length $1.15 \mathrm{~mm}(1.02-1.17 \mathrm{~mm}$, $\mathrm{n}=4)$; CR $0.45(0.46-0.52, \mathrm{n}=4)$; macrotrichia numerous (Fig. 6); first radial cell slit-like, second cell open (Fig. 7). Legs brown, except tarsi pale brown.

Genitalia (Figs 8-11). Apicolateral process of tergite 9 short, with five short bristles. Posterior margin of sternite 9 with triangular projection on each lateral side and a pair of horn-like projections. Gonostylus straight, basally broad, apically slender, proximal part covered by small setae, two long bristles at midpoint present (Figs 8-9). Parameres asymmetrical. Posterior process of parameres fused to right arm, tapering evenly along its length, evenly curved dorsad (Fig. 10). Aedeagus high arched, with apicolateral processes twisted along its length, tapering apically (Fig. 11).

\section{Female}

Unknown.

\section{Remarks}

Dasyhelea dominiakae sp. nov. is a member of the subgenus Dicryptoscena and is similar to D. notata and $D$. modesta. What distinguishes this species from those mentioned above, as well as other European species of Dicryptoscena, is the presence of triangular projections located on sternite 9. The male of $D$. dominiakae sp. nov. further differs from D. notata in having an evenly shaped posterior process and it is also separated from $D$. modesta by the equal length of the fourth and fifth palpal segments.

\section{Biology}

The holotype and paratypes were collected with Malaise traps in an old limestone quarry in the south of Sweden during May-June, among Salix caprea Linnaeus next to a pond.

\section{Dasyhelea (Dicryptoscena) gothlandica sp. nov. urn:lsid:zoobank.org:act:5FCC2057-325D-4EFF-B0F9-0C660A747422}

Figs $12-32$

\section{Diagnosis}

The male genitalia of this species are characteristic in having the posterior margin of sternite 9 with a pair of processes apically separated by a shallow furrow. Gonostyli short, tapering to an indented sharp point. The aedeagus has broad apicolateral processes, and the posterior process of the paramere has fine hairs apically.

\section{Etymology}

Gothlandica refers to Gotland, a calcareous island located in the Baltic Sea east of mainland Sweden, where the holotype was collected.

\section{Type material}

\section{Holotype}

SWEDEN: $\overbrace{}^{\top}$, Gotland, Bästeträsk, $57.899383^{\circ} \mathrm{N}, 18.901083^{\circ} \mathrm{E}, 9$ masl, Malaise trap, 28 May-12 Jun. 2011, leg. B. Eklund (NHRS) (DNA voucher: 4BA).

\section{Paratypes}

SWEDEN: $2 \hat{\jmath} \hat{\partial}, 2$ 2 ㅇ, same data as holotype; $1 \hat{\jmath}$, Gotland, Horsan, $57.865883^{\circ} \mathrm{N}, 18.846350^{\circ} \mathrm{E}$, 4 masl, Malaise trap, 10-25 Jul. 2011, leg. B. Eklund (NHRS); 1 స, 2 우, Gotland, Bästeträsk, $57.899383^{\circ} \mathrm{N}, 18.901083^{\circ} \mathrm{E}, 9$ masl, sweep net, 3 Jul. 2011, leg. J. Strandberg (NHRS) (DNA voucher: 6AW). 

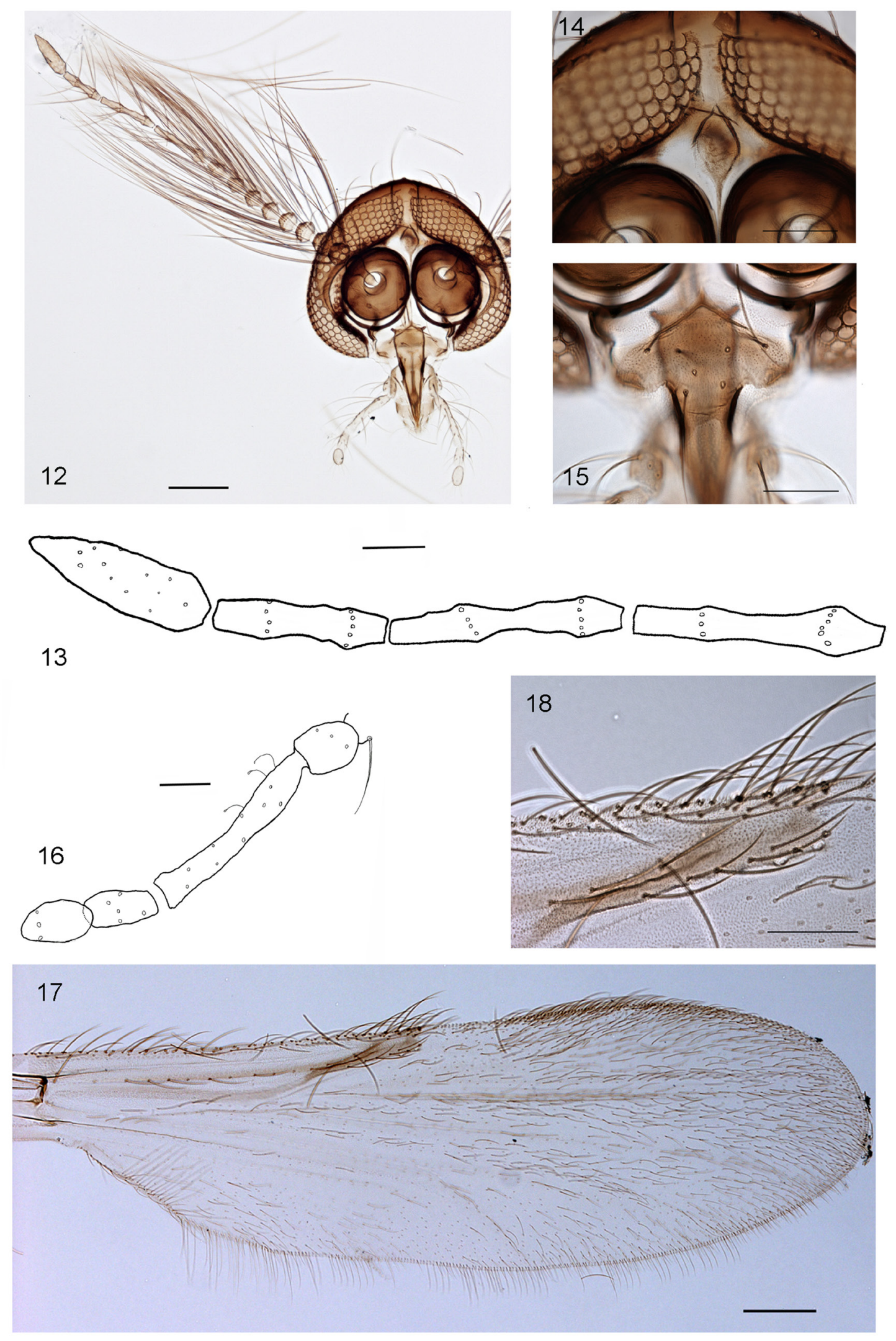

Figs 12-18. Dasyhelea gothlandica sp. nov., holotype, ô. 12. Head. 13. Distal flagellomeres. 14. Frontal sclerite. 15. Clypeus. 16. Palp. 17. Wing. 18. First and second radial cell of wing. Scale bars: $12,17=$ $100 \mu \mathrm{m} ; 14,18=50 \mu \mathrm{m} ; 13,15-16=25 \mu \mathrm{m}$. 


\section{Description}

\section{Male}

HEAD (Figs 12-16). Antennal flagellum length $727 \mu \mathrm{m}(687-727 \mu \mathrm{m}, \mathrm{n}=4)$; AR $1.06(0.97-1.19, \mathrm{n}=4)$ (Fig. 13). Frontal sclerite elliptical (Fig. 14). Clypeus entire, with $8(6-8, n=4)$ long setae (Fig. 15). Palp segment 3 slender, $90 \mu \mathrm{m}(85-91 \mu \mathrm{m}, \mathrm{n}=4) ; \mathrm{PR}_{\text {(III) }} 6.6(6.3, \mathrm{n}=4)$ (Fig. 16); first half with hyaline sensillae on inner surface.

Thorax (Figs 17-18). Scutellum pale, with 10 bristles $(9-10, \mathrm{n}=4)$. Wing length $1.15(1.08-1.17 \mathrm{~mm}$, $\mathrm{n}=4)$; CR $0.45(0.46-048, \mathrm{n}=4)$; macrotrichia numerous (Fig. 17); first radial cell slit-like, second cell open (Fig. 18). Legs light brown, tarsi paler.

Genitalia (Figs 19-22). Apicolateral process of tergite 9 short. Posterior margin of sternite 9 apically divided into pair of obtuse projections. Gonostylus short, tapering to indented sharp point, covered by small setae, two long bristles at midpoint present (Figs 19-20). Parameres asymmetrical; posterior process fused with right arm; long and slender, distinctly bent apically, with fine apical hairs (Fig. 21). Aedeagus low arched with apicolateral processes broad, somewhat folded, extended laterally in distal part (Fig. 22).
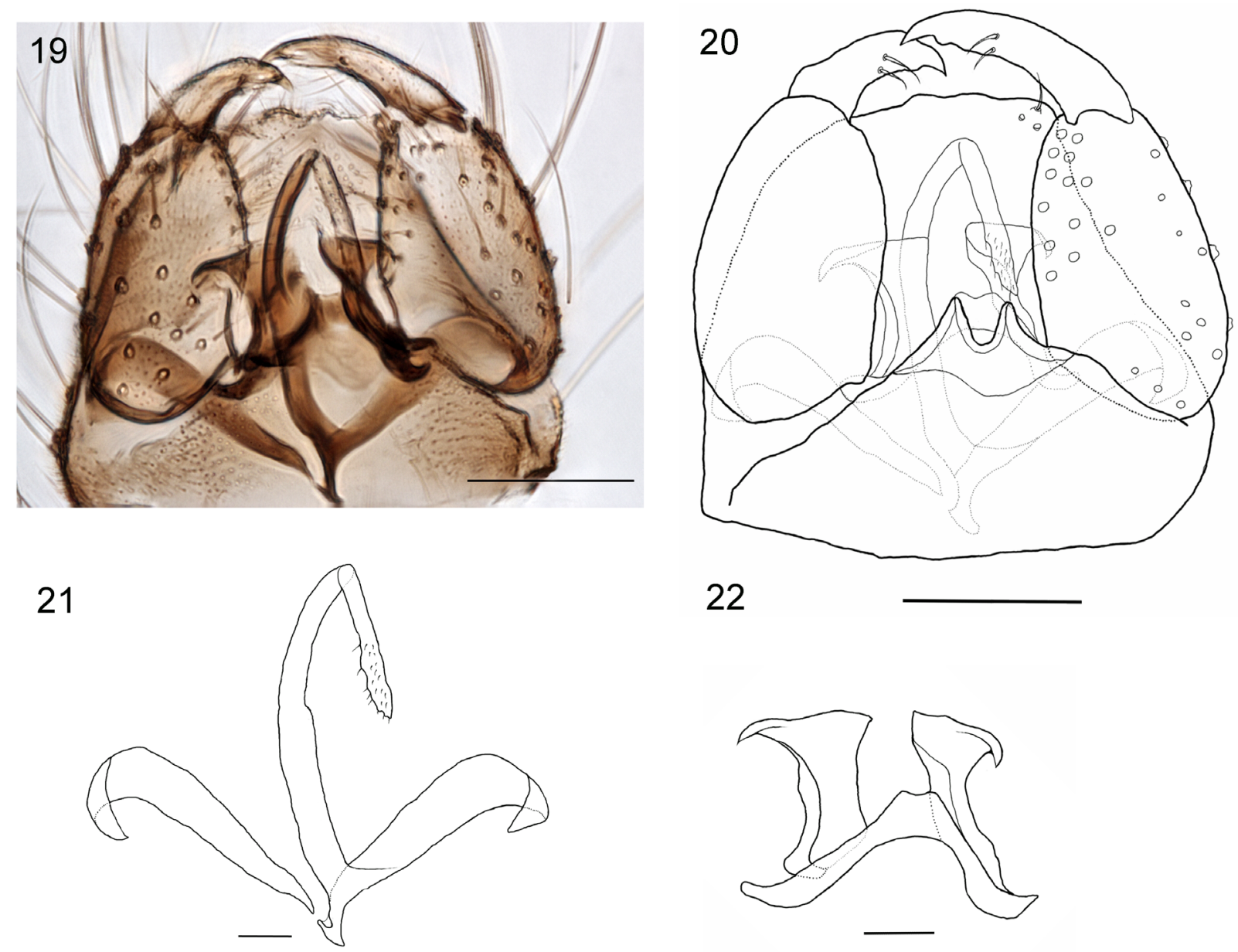

Figs 19-22. Dasyhelea gothlandica sp. nov., holotype, $\overbrace{}^{\lambda}$.19-20. Ventral aspect of genitalia. 21. Parameres. 22. Aedeagus. Scale bars: $19-20=50 \mu \mathrm{m} ; 21-22=16 \mu \mathrm{m}$. 

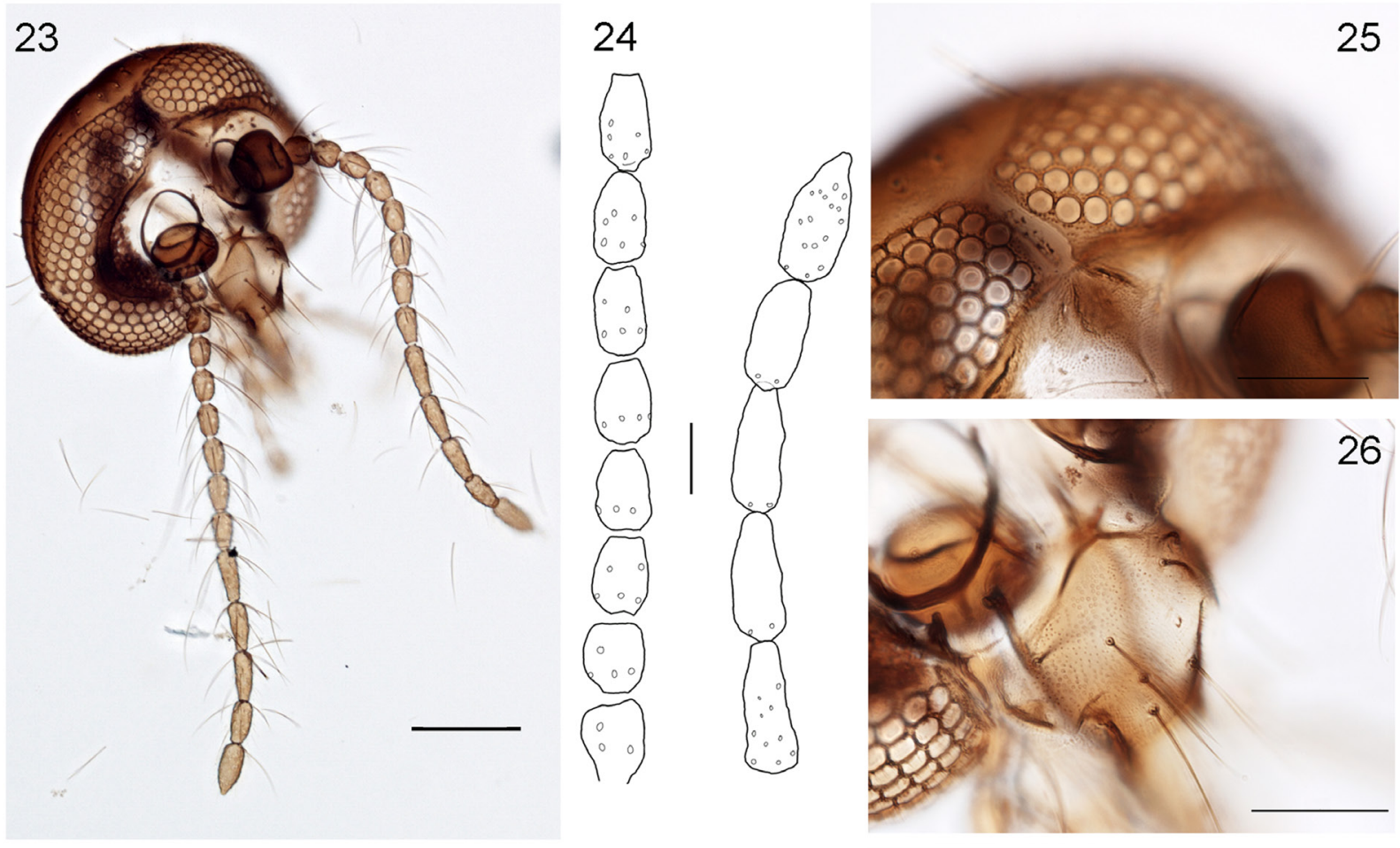

27
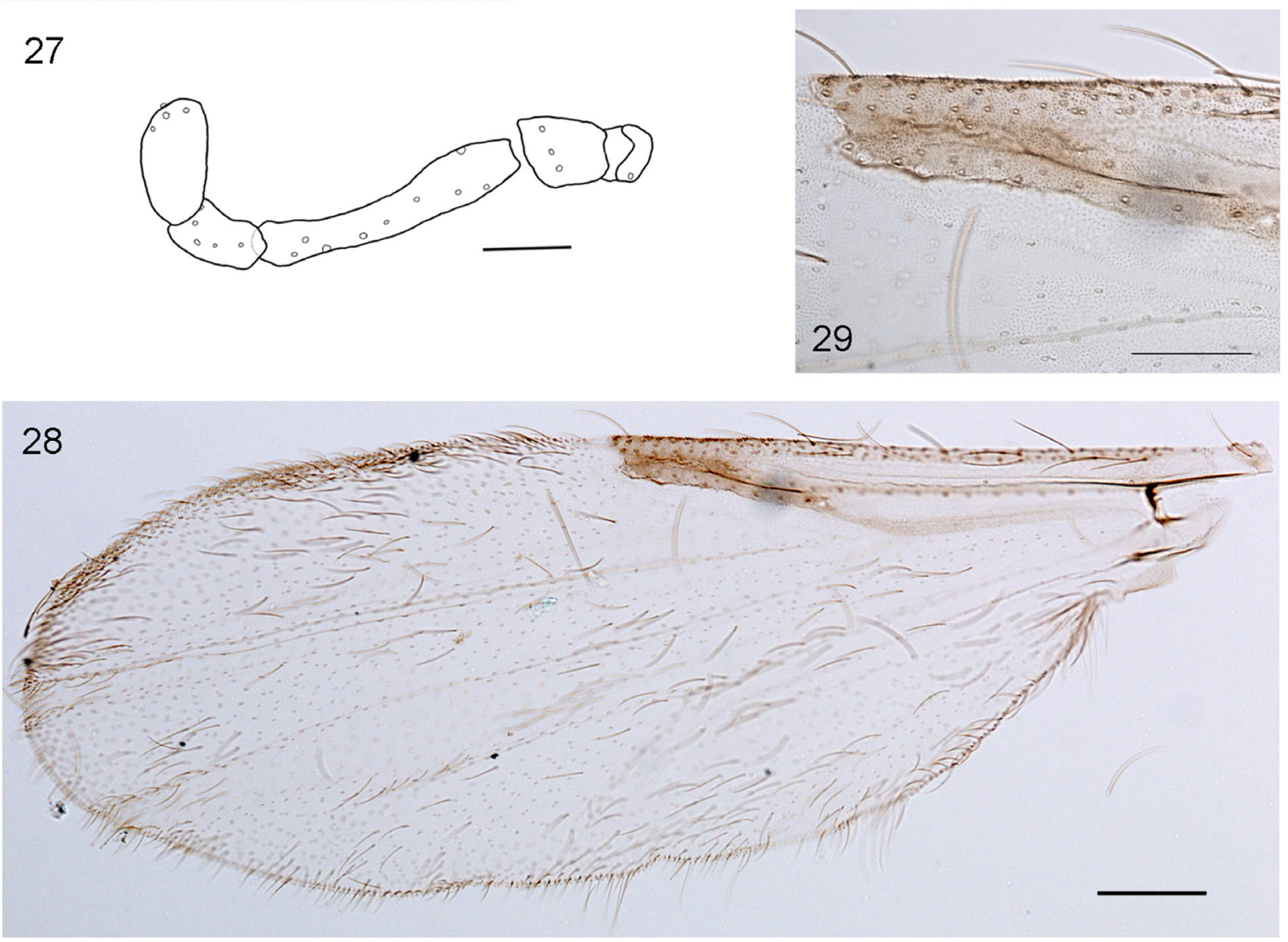

Figs 23-29. Dasyhelea gothlandica sp. nov., paratype,, . 23. Head. 24. Flagellomeres. 25. Frontal sclerite. 26. Clypeus. 27. Palp. 28. Wing. 29. First and second radial cell of wing. Scale bars: $23,28=100 \mu \mathrm{m}$; $25-26,29=50 \mu \mathrm{m} ; 24,27=25 \mu \mathrm{m}$. 


\section{Female}

HEAD (Figs 23-27). Antennal flagellum length $545 \mu \mathrm{m}(444-525, \mathrm{n}=3)$; distal flagellomeres elongate; AR $0.96(0.86-1.0, n=3)$ (Fig. 24). Clypeus entire, with $8(\mathrm{n}=3)$ long setae (Fig. 25). Frontal sclerite elliptical (Fig. 26). Palp segment 3 slender, $80 \mu \mathrm{m}(80 \mu \mathrm{m}, \mathrm{n}=4)$; $\mathrm{PR}_{\text {(III) }} 5.6(5.3, \mathrm{n}=3)$ (Fig. 27); with hyaline sensillae at basal part of inner surface.

Thorax (Figs 28-29). Scutellum pale, with 8 bristles $(9-10, \mathrm{n}=3)$. Wing length $1.1 \mathrm{~mm}(1.05-1.13$, $\mathrm{n}=3$ ); CR $0.46(0.44-0.47, \mathrm{n}=3$ ) (Fig. 28). First radial cell slit-like, second cell open but small (Fig. 29). Legs as in male.

Genitalia (Figs 30-32). Subgenital plate with notum separated from ramus, slightly fragmented (Figs 30-31). Spermatheca single; ovoid-shaped with short neck; length $\times$ width: $60 \times 40 \mu \mathrm{m}(60 \times 40 \mu \mathrm{m}$, $\mathrm{n}=3$ ) (Fig. 32).

\section{Remarks}

This species is a member of the subgenus Dicryptoscena, and the male is similar to that of Dasyhelea albidipes Santos Abreu, 1918 in the morphology of the genitalia, particularly by the presence of a pair of processes on the posterior margin of sternite 9 . D. gothlandica sp. nov. differs from $D$. albidipes by the broadly shaped apicolateral processes and the short gonostyli.

\section{Biology}

The holotype was collected in a Malaise trap next to Lake Bästeträsk, with sourrounding vegetation consisting of Pinus sylvestris Linnaeus and small shrubs. One of the male paratypes was collected in a Malaise trap next to Lake Horsan, approximatley $5 \mathrm{~km}$ south-east of Bästeträsk.
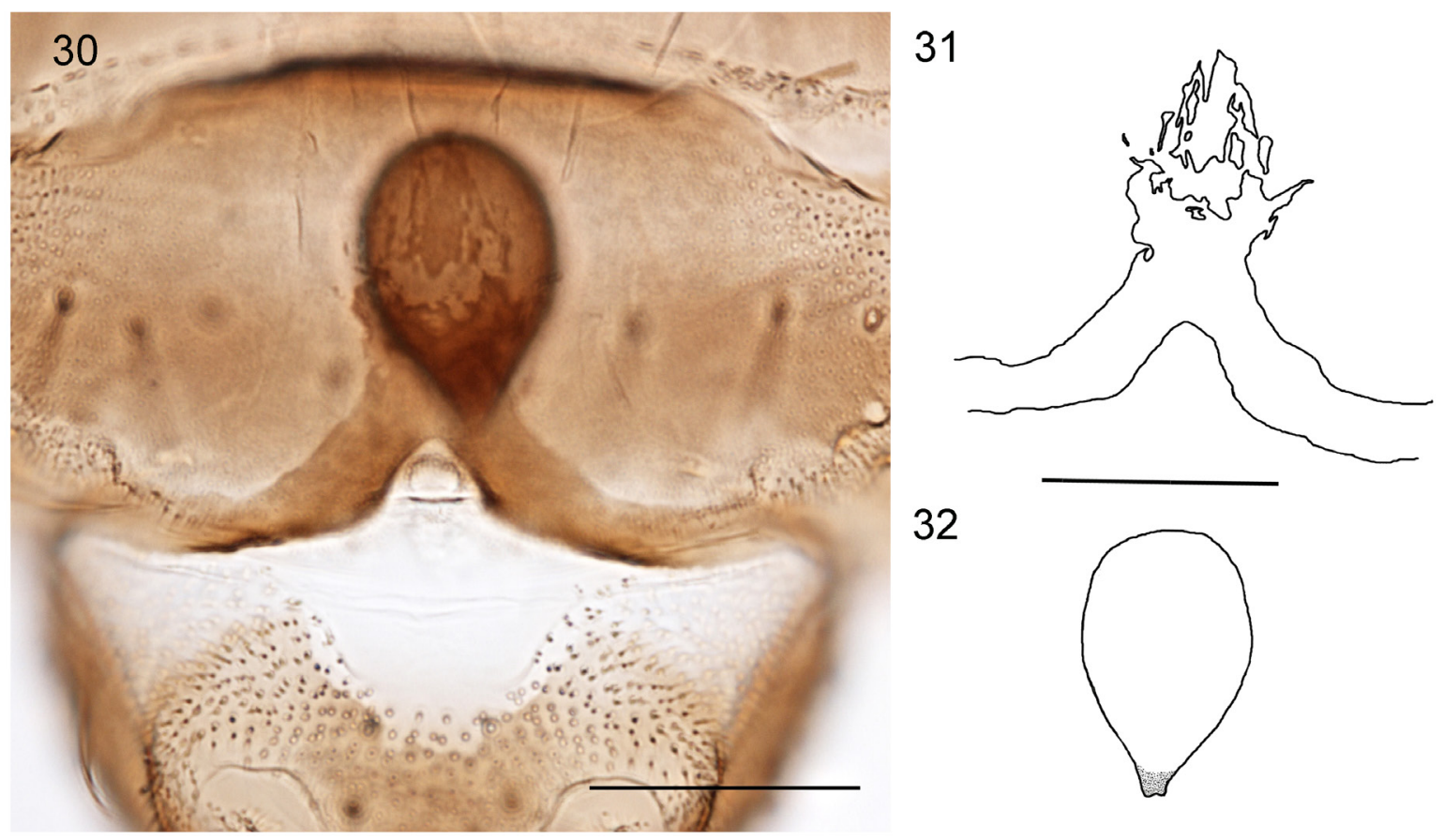

Figs 30-32. Dasyhelea gothlandica sp. nov., paratype, + . 30-31. Subgenital plate. 32. Seminal capsule. Scale bars $=50 \mu \mathrm{m}$. 
Sebessia Remm, 1979: 55. Type species: Dasyhelea flavopyga Zilahi-Sebess, 1940: 49 (by original designation).

Dasyhelea (Sebessia) acuminata Kieffer, 1919

Dasyhelea acuminata Kieffer, 1919: 60.

Dasyhelea polita Edwards, 1921: 124.

Dasyhelea verticillata Kieffer, 1925a: 63.

Dasyhelea littoralis Goetghebuer, 1934: 289.

\section{New records}

SWEDEN: 1 đે, Mörbylånga, Frösslunda alvar, northeastern part, $56.547450^{\circ} \mathrm{N}, 16.577250^{\circ} \mathrm{E}$, Trap ID 20, collecting event 1498, Malaise trap, 5 Jul.-2 Aug. 2005, leg. Swedish Malaise Trap Project (NHRS); 3 우오, Gotland, Lärbro, $57.847400^{\circ}$ N, $18.811216^{\circ}$ E, 6 masl, net, 3 Jul. 2011, leg. J. Strandberg (NHRS).

\section{Distribution}

Great Britain (Scotland), Estonia, Belgium, France, Czech Republic, Hungary, Bulgaria (Dominiak \& Szadziewski 2010).

\section{Biology}

The male was collected next to a pasture and the females from the vegetation in a marsh.

\section{Discussion}

The two new species belong to the subgenus Dicryptoscena and together with the new records the Swedish Dasyhelea fauna now contains 20 species, representing the five subgenera, i.e., Dasyhelea (6 spp.), Dicryptoscena (5 spp.), Prokempia (2 spp.), Pseudoculicoides (6 spp.) and Sebessia (1 sp.). The number of Dasyhelea species in neighboring countries ranges from 8 for Finland (Huldén \& Huldén 2014), to 11 for both Norway and Germany (Stur \& Borkent 2014; Szadziewski et al. 2012), 12 for Lithuania, and 30 in both Estonia and Poland (Szadziewski et al. 2012). According to Peterson \& Achim (2001) there are 4 species likely to occur in Denmark based on distributional patterns, and Remm (1988), without locality data, lists Dasyhelea dampfi as having a distribution that includes Latvia. Comparing the species composition between neighbouring countries, there are now six species present in Sweden that have also been reported from either Norway or Finland. The species D. bensoni, D. bilineata and D. modesta are present in all three countries. Sweden shares 13 species with Estonia and Poland of which 8 are present in all three countries (Szadziewski et al. 2012). Dasyhelea flavoscutellata (Zetterstedt, 1850) has not been recorded from Sweden but is present in all the countries mentioned above except Lithuania, Denmark and Latvia, and is therefore likely to live in Sweden as well. Most of the new records for Sweden have been collected from the southern parts of the country and only two records are from a northern locality (Muddus National Park). The diversity from a major part of Sweden is thus poorly known and could probably yield many more species. The substantial increase of Dasyhelea species in Sweden probably signals that the knowledge of Dasyhelea in particular and Ceratopogonidae in general is poor.

\section{Acknowledgements}

The authors are grateful for the help in identifications provided by Dr. Patrycja Dominiak and Dr. Ryszard Szadziewski at the Department of Invertebrate Zoology and Parasitology, University of Gdansk, Poland. For making material available for this study we are particularly indebted to Kajsa Glemhorn, Station 
Linné, Öland, Sweden and the staff of the Museum of Zoology in Lund, Sweden. We are very thankful to Mr. Bertil Eklund, Gotland, Sweden and Mr. Hans Gustafsson, Gällivare, Sweden for emptying Malaise traps. We are much obliged for the assistance in the lab provided by Dr. Tobias Malm (NHRS). This study was funded by The Swedish Taxonomy Initiative (dha 157/09 1.4).

\section{References}

Borkent A. 2015. World Species of Biting Midges (Diptera: Ceratopogonidae). Available from http:// wwx.inhs.illinois.edu/files/7613/9136/7587/WorldCatalogtaxa.pdf [accessed 17 Feb. 2015]

Borkent A. \& Wirth W. 1997. World species of biting midges (Diptera: Ceratopogonidae). Bulletin of the American Museum of Natural History 233: 1-257. Available from http://digitallibrary.amnh.org/dspace/ handle/2246/7 [accessed 18 Jun. 2015]

Brodskaya N.K. 1995. A new species of biting midge of the genus Dasyhelea Kieff. (Diptera, Ceratopogonidae) from Leningrad Region. International Journal of Dipterological Research 7: 193196.

Chandler P.J., Ashe P. \& Connor J.P. 2008. Notes on Ceratopogonidae (Diptera) including some new national records for Britain and Ireland. Dipterists Digest 15: 73-94.

Clastrier J. 1966. Cératopogonidés des iles Canaries (Dipt. Nematocera). Annales de la Société Entomologique de France, N.S. 2: 693-710.

Coquilett D.W. 1901. New Diptera in the U.S. National Museum. Proceedings of the United States National Museum 23: 593-618. Available from http://www.biodiversitylibrary.org/item/32360\#page/663/ mode/1up [accessed 14 Jun. 2015]

Disney R.H.L. 1975. A midge (Diptera, Ceratopogonidae) new to Britain that is abundant in the limestone pavement of the Yorkshire Pennies. Entomologist's Monthly Magazine 118: 233-234.

Domniak P. 2005. Biting midges (Diptera: Ceratopogonidae) developing in hollows and sap of various species of trees. Dipteron 21: 5-6.

Domniak P. 2012. Biting midges of the genus Dasyhelea Kieffer (Diptera: Ceratopogonidae) in Poland. Polish Journal of Entomology 81: 211-304.

Domniak P. \& Szadziewski R. 2006. Biting midges of the genus Dasyhelea Kieffer, 1911 (Diptera: Ceratopogonidae) collected from Polish peat-bogs. Dipteron 22: 4-7.

Dominiak P. \& Szadziewski R. 2010. Distribution and new synonymy in European biting midges of the genus Dasyhelea Kieffer (Diptera: Ceratopogonidae). Zootaxa 2437: 1-37.

Edwards F.W. 1921. Diptera Nematocera from Arran and Loch Etive. Scottish Naturalist 109-110: 5961, 89-92, 121-125. Available from http://www.biodiversitylibrary.org/item/87922\#page/65/mode/1up [accessed 14 Jun. 2015]

Edwards F.W. 1929. British non-biting midges (Diptera, Chironomidae). Transactions of the Royal Entomological Society of London 77: 279-430. http://dx.doi.org/10.1111/j.1365-2311.1929.tb00692.x

Edwards F.W. 1933. Some Pertshire Diptera. Scottish Naturalist 201: 87-92.

Enderlein G. 1936. Ordnung: Zweiflügler, Diptera. Abt. 16. In: Brohmer P., Ehrmann P. \& Ulmer G. (eds) Die Tierwelt Mitteleuropas 6: Insekten: 259. Part III. Quelle \& Meyer, Leipzig.

Glukhova V.M. 1981. A comparative morphological review of the mouthparts of the females and the males in the subfamilies Dasyheleinae and Forcipomyiinae (Diptera: Ceratopogonidae). Entomologiceskoe Obozreine 60: 62-76. 
Glukhova V.M. \& Brodskaya N.K. 1997. Description of a new species of non-blood-sucking biting midge of the genus Dasyhelea Kieffer (Diptera, Ceratopogonidae) from Karelia. Entomologiceskoe Obozrenie 76: 443-447.

Goetghebuer D.M. 1919. Observations sur les larves et nymphes de quelques Chironomides de Belgique. Annales de Biologie Lacustre 9: 51-78. Available from http://www.biodiversitylibrary.org/ item/28396\#page/59/mode/1up [accessed 14 Jun. 2015]

Goetghebuer D.M. 1920. Ceratopogoninae de Belgique. Mémoires du Musée Royal d'Histoire Naturelle de Belgique 8 (3): 2-116. Available from http://www.biodiversitylibrary.org/item/133957\#page/241/ mode/1up [acces-sed 14 Jun. 2015]

Goetghebuer D.M. 1921. Chironomides de Belgique et spécialement de la zone des Flandres. Mémoires du Musée Royal d'Histoire Naturelle de Belgique 8 (4): 1-208. Available from http://www. biodiversitylibrary.org/item/133957\#page/363/mode/1up [accessed 14 Jun. 2015]

Goetghebuer D.M. 1931. Ceratopogonidae et Chironomidae nouveaux d'Europe. Bulletin de Belgique. Annales de Biologie Lacustre 15: 93-104.

Goetghebuer D.M. 1934. Ceratopogonidae et Chironomidae nouveaux ou peu connus d'Europe. Bulletin et Annales de la Société Entomologique de Belgique 74: 287-294.

Gosseries J. 1991. Ceratopogonidae. In: Grootaert P., de Bruyn L. \& de Meyer M. (eds) Catalogue of the Diptera of Belgium. Institut Royal des Sciences Naturelles de Belgique, Documents de Travail 70: $41-45$.

Graves R.C. \& Graves A.C.F. 1985. Diptera associated with shelf fungi and certain other microhabitats in the highlands area of western North Carolina. Entomological News 96: 87-92.

Guérin M.F.E. 1833. Notice sur les métamorphoses des Cératopogons et description de deux espèces nouvelles de ce genre, découvertes aux environs de Paris. Annales de la Société Entomologique de France 2: 161-167. Available from http://www.biodiversitylibrary.org/item/100631\#page/167/ mode/1up [accessed 14 Jun. 2015]

Huldén L. \& Huldén L. 2014. Checklist of the family Ceratopogonidae (Diptera) of Finland. In: Kahanpää J. \& Salmela J. (eds) Checklist of the Diptera of Finland. ZooKeys 441: 53-61. http://dx.doi. org/10.3897/zookeys.441.7742

Kieffer J.J. 1911. Nouvelles descriptions de chironomides obtenus d'éclosion. Bulletin de la Société d'Histoire Naturelle de la Moselle 27: 1-60.

Kieffer J.J. 1913a. Nouvelle étude sur les chironomides de l'Indian Museum de Calcutta. Records of the Indian Museum 9: 119-197.

Kieffer J.J. 1913b. Nouvelle contribution à la connaissance des tendipédides d'Allemagne. Bulletin de la Société d'Histoire Naturelle de la Moselle 28: 37-44.

Kieffer J.J. 1918. Beschreibung neuer, auf Lazarettschiffen des östlichen Kriegsschauplatzes und bei Ignalio in Litauen von Dr. Horn gesammelter Chironomiden, mit Übersichtstabellen einiger Gruppen von paläarktischen Arten (Dipt.). Entomologische Mitteilungen 7: 35-188. Available from http://www. biodiversitylibrary.org/item/40402\#page/51/mode/1up [accessed 14 Jun. 2015]

Kieffer J.J. 1919. Chironomides d'Europe conservés au Musée National Hongrois de Budapest. Annales Musei Nationalis Hungarici 17: 1-160.

Kieffer J.J. 1923. Ceratopogonines recueillis au Sahara Constantinois. Archives de l'Institut Pasteur d'Algérie 1: 654-683.

Kieffer J.J. 1925a. Diptères (Nématocères piqueurs): Chironomidae Ceratopogoninae. Faune de France 11: $1-139$. 
Kieffer J.J. 1925b. Chironomiden der Hochmoore Nordeuropas und des östlichen Mitteleuropas. Beiträge zur Kunde Estlands 10: 145-163.

Kieffer J.J. 1925c. Nouveaux genres et nouvelles espèces de Chironomides piqueurs. Archives de l'Institut Pasteur d'Algérie 3: 405-430.

Laboulbène A. 1869. Histoires des métarmorphoses du Ceratopogon dufouri. Annales de la Société Entomologique de France, Series 4, 9: 157-166. Available from http://www.biodiversitylibrary.org/ item/101299\#page/163/mode/lup [accessed 14 Jun. 2015]

Macfie J.W.S. 1943. Ceratopogonidae (Diptera) from Egypt. Proceedings of the Royal Entomological Society of London B 12: 145-159. http://dx.doi.org/10.1111/j.1365-3113.1943.tb00763.x

Malloch J.R. 1915. The Chironomidae, or midges, of Illinois, with particular reference to the species occuring in the Illinois River. Bulletin of the Illinois State Laboratory of Natural History 10: 275-543. Available from http://www.biodiversitylibrary.org/item/34962\#page/323/mode/1up [accessed 14 Jun. 2015]

Mayer K. 1934. Die Metamorphose der Ceratopogonidae (Dipt.): ein Beitrag zur Morphologie, Systematik, Ökologie und Biologie der Jugendstadien dieser Dipterenfamilie. Archiv für Naturgeschichte 3: 205-288.

Meigen J.W. 1830. Systematische Beschreibung der Bekannten Europäischen Zweiflügeligen Insekten, Vol. 6. Schulzische Buchhandlung, Hamm. Available from http://www.biodiversitylibrary.org/ item/45860\#page/9/mode/1up [accessed 14 Jun. 2015]

Mik J. 1888. Zur Biologie von Ceratopogon Meig., nebst Beschreibung einer neuen Art dieser Gattung. Wiener Entomologische Zeitung 7: 183-192. Available from http://www.biodiversitylibrary.org/ item/43819\#page/207/mode/1up [accessed 14 Jun. 2015]

Nielsen S.A., Nielsen B.O. \& Chirico J. 2010. Monitoring of biting midges (Diptera: Ceratopogonidae: Culicoides Latreille) on farms in Sweden during the emergence of the 2008 epidemic of bluetongue. Parasitology Research 106: 1197-1203. http://dx.doi.org/10.1007/s00436-010-1791-4

Petersen F.T. \& Achim S. 2001. Ceratopogonidae. In: Petersen F.T. \& Meier R. (eds) A preliminary list of the Diptera of Denmark. Steenstrupia 26: 136-138.

Przhiboro A.A. 1999. The quantitative characteristics of Diptera (Insecta) of the shallow littoral zone of small lakes in North Karelia. Proceedings of the Zoological Institute of the Russian Academy of Sciences 281: $129-134$.

Przhiboro A.A. 2005. New data on Ceratopogonidae from lake shore habitats in NW Russia (Diptera). Zoosystematica Rossica 14: 165-167.

Rehnberg E. \& Brodin Y. 2010. Svidknott (Diptera, Ceratopogonidae) - irriterande okända. Entomologisk Tidskrift 131: 169-176.

Remm H. 1962. The genus Dasyhelea Kieffer in Estonia (Diptera, Heleidae). Tartu Riikliku Ülikooli Toimetised 120: 108-133.

Remm H. 1972. New species of Ceratopogonidae (Diptera) from the South Siberia. Tartu Riikliku Ülikooli Toimetised 293: 62-90.

Remm H. 1979. A catalogue of the Ceratopogonidae (Diptera) of the Estonian S.S.R. Eesti NSV Teaduste Akadeemia Tartu: 40-60.

Remm H. 1988. Family Ceratopogonidae. In: Soos Á. \& Papp L. (eds) Catalogue of Palaearctic Diptera, Vol. 3. Akadémiai Kiadó, Budapest. 
Remm H. 1993. New species of Ceratopogonidae (Diptera) from the CIS. Izviestia Akademii Nauk Estonii, Biologia 42: 180-200.

Remm H. \& Zhogolev D.T. 1968. Contributions to the fauna of biting midges (Diptera, Ceratopogonidae) of the Crimea. Entomologiceskoe Obozrenie 47: 826-842.

Remmert H. 1953. Dasyhelea tecticola n. sp., eine Ceratopogonidae aus Regenrinnen (Diptera: Ceratopogonidae). Beiträge zur Entomologie 3: 333-336.

Spâtaru P. \& Damian-Georgescu A. 1970. Metamorfoza la Dasyhelea mayeri n. sp. si Dasyhelea thienemanni n. sp. (Ceratopogonidae, Diptera). Studii si Cercetari de Biologie, Seria Zoologie 22: 421431.

Strandberg J. \& Johanson K.A. 2010. The historical biogeography of Apsilochorema (Trichoptera, Hydrobiosidae) revised, following molecular studies. Journal of Zoological Systematics and Evolutionary Research 49: 110-118. http://dx.doi.org/10.1111/j.1439-0469.2010.00578.x

Strenzke K. 1950. XI. Anhang. Dasyhelea lithotelmatica n. sp. In: Thienemann A. (ed.) Lunzer Chironomiden. Ergebnisse von Untersuchungen der stehenden Gewässer des Lunzer Seengebietes (Niederösterreich). Archiv für Hydrobiologie, Suppl. 18: 178-187.

Strobl B.G. 1910. Die Dipteren von Steiermark. II. Nachtrag. Mitteilungen des Naturwissenschaftlichen Vereines für Steiermark 46: 45-293. Available from http://www.biodiversitylibrary.org/item/93344\#page/ 593/mode/1up [accessed 23 Jun. 2015]

Stur E. \& Borkent A. 2014. When DNA barcoding and morphology mesh: Ceratopogonidae diversity in Finnmark, Norway. ZooKeys 463: 95-131. http://dx.doi.org/10.3897/zookeys.463.7964

Szadziewski R. 1983. Flies (Diptera) of the saline habitats of Poland. Polish Journal of Entomology 53: $31-76$.

Szadsziewski R. 1986. Redescription and notes on some Ceratopogonidae (Diptera). Polish Journal of Entomology 56: 3-103.

Szadziewski R., Krzywinski J. \& Gilka W. 1997. Diptera, Ceratopogonidae, biting midges. In: Nilsson A. (ed.) Aquatic Insects of North Europe - A Taxonomic Handbook 2: 243-263. Apollo Books, Stenstrup.

Szadziewski R., Gwizdalska-Kentzer M. \& Gilka W. 2011. Order Diptera, family Ceratopogonidae. In: van Harten A. (ed.) Arthropod Fauna of the United Arab Emirates 4: 636-653. Dar Al Ummah Printing, Abu Dhabi.

Szadziewski R., Borkent A. \& Dominiak P. 2012. Ceratopogonidae. In: de Jong H. \& Pape T. (eds) Fauna Europaea: Diptera: Nematocera. Fauna Europaea version 2.6.2. Available from http://www. faunaeur.org [accessed 28 Jan. 2015]

Tamura K., Peterson D., Peterson N., Stecher G., Nei M. \& Kumar S. 2011. MEGA5: Molecular Evolutionary Genetics Analysis using Maximum Likelihood, Evolutionary Distance, and Maximum Parsimony Methods. Molecular Biology and Evolution 28: 2731-2739. http://dx.doi.org/10.1093/ molbev/msr121

Thienemann A. 1915. Zur Kenntnis der Salzwasser-Chironomiden. Archiv für Hydrobiologie, Suppl 2: $443-482$.

Thienemann A. 1950. Lunzer Chironomiden. Ergebnisse von Untersuchungen der stehenden Gewässer des Lunzer Seengebietes (Niederösterreich). Archiv für Hydrobiologie, Suppl. 18: 1-202.

Thomsen L.C. 1935. New species of New York State Ceratopogonidae. Journal of the New York Entomological Society 43: 283-296. 
Tokunaga M. 1963. Some Japanese biting midges breeding in paddy-field water (Diptera, Ceratopogonidae). Scientific Reports of the Kyoto Prefectural University, Agriculture 15: 37-49.

Vaillant F. 1957. Deux Ceratopogonidae nouveaux de l'Algérie. Bulletin des travaux publiés par la Station d'aquiculture et de pêche de Castiglione, N.S. 1958 (9): 263-274.

Valkanov A. 1941. Über das Auffinden von anabiotische Dipteren in Bulgarien. Godišnik na Sofijskija Universitet 37: 201-205.

Waugh W.T. \& Wirth W.W. 1976. A revision of the genus Dasyhelea Kieffer of the Eastern United States north of Florida (Diptera: Ceratopogonidae). Annals of the Entomological Society of America 69: 219-247. http://dx.doi.org/10.1093/aesa/69.2.219

Winnertz J. 1852. Beitrag zur Kenntniss der Gattung Ceratopogon Meigen. Linnaea Entomologica 6: 1-80. Available from http://www.biodiversitylibrary.org/item/155194\#page/15/mode/1up [accessed 14 Jun. 2015]

Wirth W.W. 1956. The heleid midges involved in the pollination of rubber trees in America (Diptera, Heleidae). Proceedings of the Entomological Society of Washington 58: 241-250. Available from http:// biodiversitylibrary.org/item/54813\#page/613/mode/1up [accessed 14 Jun. 2015]

Wirth W.W. 1973. Family Ceratopogonidae. In: Delfinado M.D. \& Hardy D.E. (eds) A Catalog of the Diptera of the Oriental Region, Suborder Nematocera 1: 346-388. University of Hawaii, Honolulu.

Wirth W.W. 1978. New species and records of intertidal biting midges of the genus Dasyhelea Kieffer from the Gulf of California (Diptera: Ceratopogonidae). Pacific Insects 18: 191-198.

Wirth W.W. \& Beaver R.A. 1979. The Dasyhelea (Diptera: Ceratopogonidae) from rock pools in the Southwestern United States. Journal of the North American Benthological Society 6: 72-76.

Yu Y.-X. 2008. Notes of new species of Dasyhelea and new record of Stilobezzia (Diptera: Ceratopogonidae). Sichuan Journal of Zoology 27: 165-166.

Yu Y.-X., Liu J.-H., Liu G.-P., Liu Z.-J., Hao B.-S., Yan G. \& Zhao T.-S. 2006. Ceratopogonidae of China, Insecta, Diptera. Vols 1-2. Military Medical Science Press, Beijing [2005].

Zilahi-Sebess G. 1931. Anabiotische Dipteren. Archiv für Hydrobiologie 23: 310-329.

Zilahi-Sebess G. 1936. Die Heleiden-Fauna von Szeged und Umgebung. Acta Biologica Szegediensis 4: 35-49.

Zilahi-Sebess G. 1940. Heleiden aus Ungarn. Folia Entomologica Hungarica 5: 10-133.

Manuscript received: 25 February 2015

Manuscript accepted: 1 June 2015

Published on: 30 July 2015

Topic editor: Koen Martens

Desk editor: Danny Eibye-Jacobsen

Printed versions of all papers are also deposited in the libraries of the institutes that are members of the EJT consortium: Muséum National d'Histoire Naturelle, Paris, France; Botanic Garden Meise, Belgium; Royal Museum for Central Africa, Tervuren, Belgium; Natural History Museum, London, United Kingdom; Royal Belgian Institute of Natural Sciences, Brussels, Belgium; Natural History Museum of Denmark, Copenhagen, Denmark. 